\title{
Perceptions of Green User Entrepreneurs' Performance-Is Sustainability an Asset or a Liability for Innovators?
}

\author{
Jana Möller ${ }^{1, *(D)}$ and Steffen Herm ${ }^{2}$ (D) \\ 1 Marketing-Department, School of Business \& Economics, Freie Universität Berlin, 14195 Berlin, Germany \\ 2 HTW Berlin Business School, Hochschule für Technik und Wirtschaft Berlin, 10318 Berlin, Germany; \\ herm@htw-berlin.de \\ * Correspondence: jana.moeller@fu-berlin.de
}

Citation: Möller, J.; Herm, S.

Perceptions of Green User

Entrepreneurs' Performance-Is Sustainability an Asset or a Liability for Innovators?. Sustainability 2021, 13, 3580. https://doi.org/ $10.3390 /$ su13063580

Academic Editor: Jan Kratzer

Received: 12 February 2021

Accepted: 21 March 2021

Published: 23 March 2021

Publisher's Note: MDPI stays neutral with regard to jurisdictional claims in published maps and institutional affiliations.

Copyright: (C) 2021 by the authors. Licensee MDPI, Basel, Switzerland. This article is an open access article distributed under the terms and conditions of the Creative Commons Attribution (CC BY) license (https:// creativecommons.org/licenses/by/ $4.0 /)$.

\begin{abstract}
User entrepreneurs rely on regular consumers when starting their business, for example, when raising creative and financial support. This research examines regular consumers' opinions with regard to the future business performance of green vs. non-green user entrepreneurs. We build on previous consumer behavior research on consumers' performance perceptions. Specifically, consumers perceive products that use green, environmentally friendly technologies as having inferior performance compared to products that use traditional technologies. We investigate whether this so called "sustainability liability" effect can also be found in consumers' perceptions of green user entrepreneurs' performance. We ran an online scenario experiment with regular consumers who assessed the business performance of several (green vs. non-green) user entrepreneurs. Results reveal a "sustainability asset" effect for perceptions of green user entrepreneurs, such that consumers with strong environmental values perceived the business performance of green user entrepreneurs as superior compared to non-green user entrepreneurs. Consumers with weak environmental values perceived green and non-green entrepreneurs as equally performant. We discuss possible explanations of our findings. Furthermore, we propose potential consequences of our results both for consumers' intentions to support user entrepreneurs as well as for user entrepreneurs' motivation to engage in green innovations.
\end{abstract}

Keywords: sustainable innovation; green innovation; user entrepreneur; user innovator; sustainability liability; sustainability asset

\section{Introduction}

Innovation is a key driver of sustainable development [1] and research has identified the relevance of users in creating value through innovations (e.g., [2,3]). For the most part, users innovate but do not commercialize their innovations. Instead, users benefit from using their own innovations and then allow manufacturers to commercialize these innovations. Another possible pathway for user innovators is to become user entrepreneurs [4].

When launching a business, user entrepreneurs use various resources. Importantly, they rely heavily on others' support to start their business [5,6], including that of experts and professional investors, as well as people from their personal life and regular, non-expert consumers who believe in the business' future success.

When thinking about starting a business, apparently there has never been a better time to innovate sustainable products. Surveys document a rising willingness of consumers to support green companies and purchase sustainable offerings even while living with the COVID-19 pandemic, or perhaps because of it [7]. The rising pressure of environmental degradation, pollution, and climate change urge consumers to rethink their consumption pattern. Companies that adapt to these changing demands are more likely to establish strategic benefits and thrive in the long term (e.g., [8,9]).

However, when it comes to acting green, there is a prevalent intention-behavior gap, such that consumers do not follow through with their wallets (e.g., [10]). White et al. [11] 
provide an extensive literature review of the barriers that are responsible for the misalignment of consumers' behavior and their stated attitudes. The authors discuss ways to shift consumers' behaviors to be more sustainable. One of their conclusions is that discontinuity helps to disrupt unsustainable habits. Major life changes make people evaluate and change their routines. For example, movers were significantly more likely than non-movers to engage in environmentally friendly behaviors, including saving gas and electricity, waste reduction, and reducing car use [12]. Similarly, the COVID-19 pandemic has dramatically changed the lives of consumers around the world and is likely to result in more sustainable behaviors.

We focus on a particular barrier to sustainable action that is grounded in consumers' perception of the performance of sustainable offerings. Earlier research has consistently shown that when consumers had to assess the functional, strength-related attributes of products, sustainable products were judged as being inferior to traditional products $[13,14]$. This so-called "sustainability liability" has been explained by consumers' compensatory beliefs that sustainability comes at the expense of performance. In this research, we examine a novel context to study this bias. In particular, we contribute to research on user entrepreneurship by investigating whether the liability effect carries over to perceptions of green user entrepreneurs' performance. In other words, we examine whether the business performance of green user entrepreneurs is perceived as inferior compared to non-green user entrepreneurs. It is important to investigate the existence of this bias because user entrepreneurs might be reluctant to engage in green innovations if doing so would cause them to be perceived as less performant.

The main purpose of our research is to test whether the sustainability liability effect also emerges in the domain of consumers' perceptions of entrepreneurial performance. In the subsequent section (Section 2), we derive our hypotheses. First, we examine the sustainability liability effect as previously studied (H1a). Second, we investigate whether user entrepreneurs that launch products that are more (vs. less) sustainable are perceived as less (vs. more) successful (H2a). Additionally, we investigate consumers' environmental values as a potential moderator ( $\mathrm{H} 1 \mathrm{~b}$ and $\mathrm{H} 2 \mathrm{~b})$. Section 3 explains the method for testing our hypotheses in a scenario experiment. To foreshadow our results (Section 4), we do not replicate the original "sustainability liability" effect for product performance and find a reverse "sustainability liability" effect for user entrepreneur performance, in particular among consumers with strong environmental values. Finally, we discuss our results (in Section 5) and contemplate whether consumers' dismissive beliefs about sustainable offerings have started to disappear as a reflection of a sustainability spirit of the time (Section 6).

\section{Theoretical Background and Hypotheses Development}

\subsection{User Innovation and Entrepreneurship}

User innovations are innovations that are created by a single company or individual in order to use it [15]. In this study, we focus on user innovations by individuals such as endusers. Companies that take a "user innovation perspective" can maximize profits if they harness the creative input of innovative end-users in designing new products and services instead of solely following a producer-only innovation approach $[15,16]$. Recent research suggests that innovation by users is very common, with users increasingly becoming the creators of new products [3,17]. For example, Franke et al. [3] estimate that about $39.7 \%$ of consumers innovate. Innovative user input might stem from, for example, user feedback, ideas, service agreements, complaints, and upgrade requests. In this study, we shift the focus away from companies. Instead, we zoom in on innovative consumers that decide to commercialize a solution they have developed by starting their own for-profit company.

User entrepreneurship describes the "new venture creation by individuals based on innovations aimed initially toward satisfying their own needs for a new or improved product or service, and subsequently produced and sold to others" [6] (p. 1119). These companies primarily introduce product innovations in the market that are based on unique 
knowledge of needs and usage context and that are likely to enter into a niche or unserved market in mature stages [6]. User entrepreneurship has occurred in various industries, e.g., medical devices, the juvenile products industry, and atomic force microscopy [6]. Innovations introduced by user entrepreneurs have ranged from small product improvements to groundbreaking new products [18]. While other sources of entrepreneurship, such as research of university scientists and companies founded by employees of incumbent firms (i.e., spin-offs), have been studied extensively, user entrepreneurship remains relatively underresearched.

User entrepreneurs' success depends on various conditions. Shah and Tripsas [4] argue that user entrepreneurship is facilitated when users enjoy the initial production of the innovation, when there are low opportunity costs, and when the industry is rich in small market niches. In a qualitative study, Hamdi-Kidar and Vellera [19] discovered the motivational factors of creative end-users to innovate and become an entrepreneur, such as user entrepreneurs' dissatisfaction with existing products, the experience of pleasure and passion in the search for new solutions, a strong belief in their success, the outlook of financial gains, and most important for our research, positive feedback and stimulation from social interactions.

\subsection{The Role of Consumers' Support for User Entrepreneurs}

When starting a business, user entrepreneurs heavily rely on others' support $[5,6]$. They gather material and immaterial resources from both experts and professional investors, as well as from people from their personal life and regular, non-expert consumers. Shah and Tripsas [5] developed a model of user entrepreneurship. They conclude that the process of user entrepreneurship diverges from the standard entrepreneurial journey. The authors show that users are often "accidental" entrepreneurs who develop an idea because of their own use and then share it with others. In contrast to the typical venture process, the development of an idea and subsequent experimentation, adaptation, and preliminary adoption often occur before users formally start a firm and enter the commercial marketplace.

Particularly, user entrepreneurs tend to engage in collective creative activities before they start their business [5]. Many user entrepreneurs benefit from the voluntary feedback, contributions, and word of mouth of community members who believe in the entrepreneur. Typically, ideas improve as a result of community interactions [5]. Furthermore, recent research has documented the growing relevance of crowdfunding for user entrepreneurs to extend their financial capital [20]. Thus, the acquisition of financial capital relies less on the traditional "seed capital to venture capital funding" model with traditional investors, angels, and venture capitalists. Rather, financial capital is raised based on other consumers' perceptions of the future business performance of user entrepreneurs. Nevertheless, like traditional investors, crowdfunding backers have to face potential losses if they personally fund products that are not attractive enough to overcome adoption hurdles.

Overall, research suggests that (green) user entrepreneurs benefit from the engagement of other consumers when starting their business. Hence, it is important that other consumers believe in the user entrepreneur's success. Next, we build our argument for a potential bias in consumers' beliefs. In particular, based on previous research on consumer behavior, we propose that user entrepreneurs who aim to market a sustainable innovation are at a disadvantage.

\subsection{The Sustainability Liability in Performance Perception}

Prior research has studied consumers' perceptions of products that used sustainable vs. traditional technologies (for an overview, see Chernev and Blair [21]). Studies have consistently documented that sustainability does not necessarily raise preferences, even if consumers care about social and environmental issues, but actually decrease preferences. The effect of a lower preference for sustainable products compared to traditional products has been termed "sustainability liability" [13]. Likewise, Lin and Chang [22] demonstrated 
that consumers perceive sustainable products to be less effective than traditional products, which results in an increased amount of product usage (e.g., mouthwash, hand sanitizer) to compensate for this perceived inferiority. Essoussi and Linton [23] investigated consumers' willingness to pay for products with recycled parts and concluded that with increased perception of the functional risk of recycled products, consumer's willingness to pay decreases. For example, recycled paper was perceived as low in functional risk while single-use cameras, auto parts, and cell phones were perceived as highly risky. Luchs et al. [13] showed that preferences depend on the type of benefit consumers value the most for a product category. For example, sustainable products were preferred when they were valued for their gentleness-related attributes, e.g., baby shampoo, and less preferred when strength-related attributes mattered for a product, e.g., car tires.

Conceptually, the sustainability liability is explained by consumers' inferences of a company's intentional resource allocation [14]. Based on the zero-sum heuristic [24,25], consumers have lay theories about company resources that are zero-sum. Accordingly, when a product is superior in one product dimension, this must be compensated by inferior performance in other dimensions. With regard to sustainable products, consumers may infer that a company that puts resources into sustainable technologies can invest less in other performance dimensions, such as functional product performance. In sum, research has repeatedly demonstrated that sustainable benefits of a product lower consumers' beliefs about its functional performance [21] (sustainability liability, H1a).

However, in their recent study, Chernev and Blair [21] found new evidence for limits of the sustainability liability. They documented the effect on perceived product performance for consumers with weak environmental values only, and showed "that for sustainabilityconscious respondents, whose moral beliefs were aligned with preserving the environment, the presence of sustainable benefits bolstered perceived product performance" (p. 9). Striving for replication of their findings, we qualify our first hypothesis by a proposed interaction $(\mathrm{H} 1 \mathrm{~b})$ :

Hypothesis 1 (H1). Consumers' performance perception of sustainable products is lower compared to consumers' performance perception of less sustainable products (H1a). This effect reverses when consumers hold strong (vs. weak) environmental values (H1b).

In our research, we extend previous research by investigating the sustainability liability effect not only in the domain of sustainable products, but also with respect to the performance perceptions of sustainable user entrepreneurs. Specifically, we propose that the sustainability liability not only decreases the consumers' product performance perceptions, but might also be observed in perceptions of a user entrepreneur's performance.

We follow the theoretical reasoning of the sustainability liability effect in the domain of product performance [13]. Thus, we argue with compensatory inferences of consumers regarding the innovator's performance: Consumers who infer a strong "green" competence of a user entrepreneur are likely to believe that the same user entrepreneur must have a lower business competence compared to a non-green user entrepreneur.

Similar to our first hypothesis, building on recent research that has demonstrated a reverse "sustainability liability" effect among consumers with strong environmental values [21], we extend our conceptual framework with moderation. We argue that the extent to which consumers value sustainability determines their evaluation of the user entrepreneur. When consumers highly value sustainability, they will be more likely to perceive the user entrepreneur as acting in alignment with their moral values [26]. As a consequence, consumers are likely to extend their positive evaluation of the user entrepreneur to his or her performance, thereby weakening and potentially overriding the negative impact of compensatory inferences on user entrepreneur performance perceptions [21]. As in H1b, we hypothesize a moderating effect of consumers' environmental values ( $\mathrm{H} 2 \mathrm{~b})$. 
Hypothesis 2 (H2). Consumers' performance perceptions of user entrepreneurs that develop sustainable products is lower compared to consumers' performance perceptions of user entrepreneurs who develop less sustainable products ( $\mathrm{H} 2 a$ ). This effect reverses when consumers hold strong (vs. weak) environmental values (H2b).

\section{Methodology}

To test our hypotheses, we conducted a scenario experiment that has been the prevailing sustainability liability research method [21]. Two hundred respondents (66\% female, age mean $(M)=38.6$ years, UK residents) recruited from Prolific (www.prolific.co; accessed on 19 March 2021) participated in an online scenario experiment in November 2020 in exchange for a small payment (£0.85). Every respondent read four scenarios and answered questions about them. The scenarios varied systematically. In particular, respondents were randomly assigned to conditions in a 2 (sustainability information: absent vs. present) $\times 4$ (product category) mixed design in which the presence of sustainability information in a scenario was varied between subjects and the sequence of products from different product categories was randomized within respondents. We used four product categories (bug spray, laundry detergent, sunscreen, and air conditioner) and short product descriptions that were developed by Chernev and Blair [21], in order to make our results comparable with previous findings.

The scenarios and corresponding questions had the same structure. First, respondents read a short profiles of male user innovators who intended to start a company and bring an innovation to market (see the full description of all scenarios in Appendix A). Next, respondents read a short description of the user innovator's product innovation (either insect spray, laundry detergent, sunscreen, or air conditioner) that either included information about sustainable features of the product (sustainability information present) or that did not include such information (control). After reading the profile and product information, respondents were asked to indicate the product's performance (see Appendix B for all measurement items). Next, we measured the respondents' perception of the user innovator. Respondents read that the user innovator was planning to present his product to several investors and to use their money to start a company. Respondents then indicated to what extent the innovator would achieve his goals and how successful his business would be ([27], Cronbach's Alpha $=0.90)$. Next, as a check for our sustainability manipulation, respondents rated their perceptions of the user innovators' products ( 2 items [21], Cronbach's alpha $=0.89$ ).

After respondents completed the ratings for the four user innovators and their product, respondents indicated their environmental values ( 2 items adapted from Chernev and Blair [21], Cronbach's alpha $=0.77)$. As further control variables related to sustainability beliefs, we asked for respondents' age, gender (coded as 1 = female, 2 = male), education, and the number of children they have. Lastly, to control for respondents' propensity for entrepreneurship, they answered to items that measured their proactive personality (5 items [28], Cronbach's alpha $=0.84)$, and their entrepreneurial experience ( 1 item: Have you ever started your own business; yes $=1$, no $=0$ ).

\section{Results}

Six respondents failed to respond to the relevant categories of our control variables and were not included in the analysis. This resulted in a final sample size of 194 respondents. Data were analyzed using SPSS Version 26.0 (64-bit) for Mac.

\subsection{Manipulation Checks}

We examined respondents' perceptions of environmental and societal benefits of the experimental stimuli (adapted from Chernev and Blair [21]), checking the effectiveness of our manipulation. For each of the four products, the respondents indicated their agreement (on 9-point scales from $1=$ Strongly disagree to $9=$ Strongly agree) to the following two statements: (a) The new product "is more environmentally friendly" than the average 
product in the product category. (b) The new product is "better for society than the average product in the product category" ([21], p. 8).

We combined both questions ( $a$ and $b$ ) to a single measure (Cronbach's alpha $=0.89$ ). Results of four separate analyses of variance (ANOVA) showed that respondents rated all products in the control condition (less sustainable product) significantly lower than products in the sustainable condition: bug spray $(\mathrm{M}=4.55 \mathrm{vs.} \mathrm{M}=7.09, p<0.01)$; laundry detergent $(M=4.45$ vs. $M=7.10, p<0.01)$; sunscreen $(M=6.05$ vs. $M=6.56, p=0.05)$; and air conditioner $(\mathrm{M}=5.40$ vs. $\mathrm{M}=6.97, p<0.01)$. These findings indicate that our sustainability manipulation was successful for every product category.

\subsection{Test of Hypotheses}

In line with findings of Chernev and Blair [21], we proposed that consumers' environmental values influence their product performance perceptions. Hence, we conducted a generalized linear regression analysis on perceived product performance with sustainability information (present vs. control), environmental values, and their interaction as independent variables. In addition, we included control variables (age, gender, education, and number of children). Since every respondent evaluated four different product category scenarios, we analyzed 776 observations. Overall, the analysis $\left(R^{2}=0.12, F(7,768)=14.65\right.$, $p<0.01)$ revealed a main effect of environmental values $(t=3.23, p<0.01)$ on product performance perception, but no main effect of sustainability information $(t=1.52, p=0.13)$. Thus, H1a was not supported.

More importantly, the analysis showed a significant interaction between sustainability information and environmental values $(\beta=0.22 ; t=2.18, p<0.05$, Table 1$)$. To explore the nature of the interaction, we compared whether there were significant differences across the sustainability information conditions at both low and high levels of environmental values. As "environmental values" is a continuous measure, we performed a spotlight analysis [29] at plus and minus one standard deviation from the mean of the environmental values (Figure 1). The planned contrast for respondents at low levels of environmental values $\left(\mathrm{M}_{\mathrm{EVlow}}=6.26\right)$ showed no statistically significant difference in their performance perception $\left(\mathrm{M}_{\text {sustainable }}=5.80 ; \mathrm{M}_{\text {control }}=6.25 ; \mathrm{t}=1.15, p=0.25\right)$. In line with $\mathrm{H} 1 \mathrm{~b}$, the planned contrast for respondents at high levels of environmental values $\left(\mathrm{M}_{\mathrm{EVhigh}}=8.62\right)$ showed that respondents expected that sustainable products perform better than their less sustainable counterparts $\left(\mathrm{M}_{\text {sustainable }}=7.35 ; \mathrm{M}_{\text {control }}=6.15 ; \mathrm{t}=3.02, p<0.01\right)$.

Table 1. Regression coefficients from the standardized variables on perceptions of product performance (a) and user entrepreneur performance (b).

\begin{tabular}{lcccc}
\hline & \multicolumn{2}{c}{ Product Performance (a) } & \multicolumn{2}{c}{ User Entrepreneur Performance (b) } \\
\hline & $\boldsymbol{\beta}$ & $\boldsymbol{p}$ & $\boldsymbol{\beta}$ & $\boldsymbol{p}$ \\
\hline Constant & 8.68 & $<0.01$ & 6.68 & $<0.01$ \\
Sustainability & 0.17 & 0.13 & 0.39 & $<0.01$ \\
Environmental values & 0.16 & $<0.01$ & 0.13 & $<0.01$ \\
Sustainability $\times$ & 0.22 & 0.03 & 0.22 & 0.02 \\
environmental values & -0.02 & $<0.01$ & -0.02 & $<0.01$ \\
Age & -0.61 & $<0.01$ & -0.60 & $<0.01$ \\
Gender & -0.16 & $<0.01$ & -0.12 & $<0.01$ \\
Education & 0.01 & 0.82 & 0.02 & 0.75 \\
Number of children & & & 0.16 & $<0.01$ \\
Proactive personality & & & 0.13 & 0.32 \\
Entrepreneurial experience & & &
\end{tabular}

In order to test our second set of hypotheses, we ran a generalized linear regression on perceived user entrepreneur performance with sustainability information (present vs. control), environmental values, and their interaction as independent variables, as well as control variables, now also including proactive personality and entrepreneurial experience. 
Overall, the regression analysis $\left(\mathrm{R}^{2}=0.14, \mathrm{~F}(9,766)=14.26, p<0.01\right)$ showed a main effect of environmental values $(t=2.74, p<0.01)$ on product performance perception, and a main effect of sustainability information $(t=3.72, p<0.01)$. Contrary to $\mathrm{H} 2 \mathrm{a}$, the regression coefficient of sustainability information was positive, indicating that green user entrepreneurs were perceived as more performant compared to non-green entrepreneurs (Table 1).

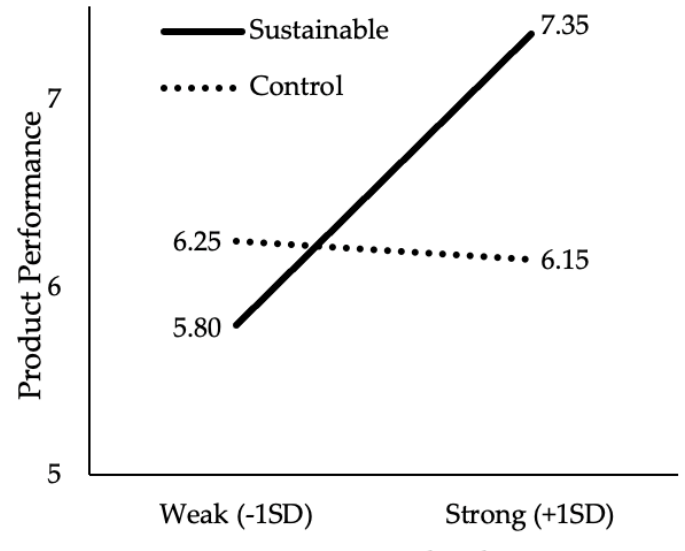

Environmental Values

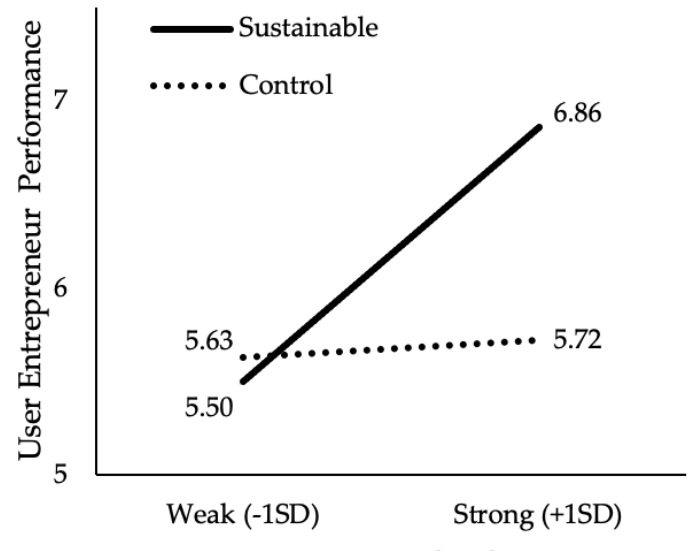

Environmental Values

(a)

Figure 1. Product performance (a) and user entrepreneur performance (b) as functions of product sustainability and respondents' environmental values.

In addition, the analysis revealed a significant interaction between sustainability information and environmental values $(\beta=0.22 ; \mathrm{t}=2.41, p<0.05)$. The results of a spotlight analysis [29] showed that at low levels of environmental values $\left(\mathrm{M}_{\mathrm{EVlow}}=6.26\right)$ there was no statistically significant difference in the respondents' performance perception $\left(\mathrm{M}_{\text {sustainable }}=5.50 ; \mathrm{M}_{\text {control }}=5.63 ; \mathrm{t}=0.43, p=0.67\right)$. In line with our $\mathrm{H} 2 \mathrm{~b}$, the planned contrast for respondents at high levels of environmental values $\left(\mathrm{M}_{\mathrm{EVhigh}}=8.62\right)$ showed significant differences in perceptions of user entrepreneur performance. In particular, respondents perceived user entrepreneurs with sustainable products as performing better than user entrepreneurs with less sustainable products $\left(\mathrm{M}_{\text {sustainable }}=6.86 ; \mathrm{M}_{\text {control }}=5.72\right.$; $\mathrm{t}=4.67, p<0.01)$.

\section{Discussion}

This research investigates whether consumers hold different beliefs about the business performance of user entrepreneurs who are either green or non-green. We motivate our research based on earlier findings in consumer research that has repeatedly demonstrated a "sustainability liability bias" in performance perceptions of green vs. non-green products. We examine whether this bias also operates in the domain of consumers' performance beliefs toward user entrepreneurs.

We conducted an online scenario experiment with two goals. First, we intended to replicate previous findings of a "sustainability liability" for green vs. non-green products (H1a and H1b). Second, we researched the prevalence of a bias for perceptions of green vs. non-green user entrepreneurs $(\mathrm{H} 2 \mathrm{a}$ and $\mathrm{H} 2 \mathrm{~b})$. The results of our study did not show a sustainability liability effect, neither for consumers' perceptions of product performance (H1a) nor for user entrepreneurs' performance (H2a). Thus, consumers did not devalue the performance of green products nor green user entrepreneurs compared to non-green alternatives. Instead, this research finds evidence for a reverse effect that we call a "sustainability asset".

Specifically, when we examined perceived product performance, we did not find a negative main effect of sustainability on performance perceptions. Thus, our results do not support prior literature (e.g., $[13,22])$. In fact, our results question whether previous 
research that showed a "sustainability liability" is still valid. In today's marketplace, consumers can increasingly choose between green products and more traditional counterparts and experience the performance of green products. Our results imply that green attributes are no longer perceived to come at the expense of performance, thus challenging the relevance of the compensatory inferences account in this stream of research for today's consumers.

However, in line with recent research [21,30], we find an interaction effect of consumers' environmental values and product sustainability on product performance perceptions. Supporting our $\mathrm{H} 1 \mathrm{~b}$, consumers with strong environmental values perceived sustainable products as more performant compared to less sustainable products. These results stress the relevance of an alignment of consumers' and products' moral values. Products that matched consumers' values were evaluated more favorably. Theoretically, this effect can be explained by motivated reasoning; that is, a consumer's goals or motives affect their evaluations [31]. Consumers with strong environmental values might process information about a green product more positive as the product is consistent with their values. Accordingly, research has shown that motivated reasoning lead consumers with strong environmental values to prefer green products because they perceived the non-green attributes of that product to be more attractive than consumers with weak environmental values [30].

More importantly for this current research, we found a positive main effect of sustainability on consumers' perceptions of user entrepreneurs' performance: consumers expected green innovators to perform better than non-green innovators. This finding contradicts our theoretical assumptions (H2a) but resonates with our results of product performance perceptions. Apparently, consumers believe in the timely relevance and the resulting business outlook of sustainable innovations, hence sustainability becomes an asset for user entrepreneurs.

In line with $\mathrm{H} 2 \mathrm{~b}$, the valuation of green user innovators was particularly prevalent among consumers with strong environmental values. This finding supports our reasoning that consumers value actors whose moral standards are aligned with their own. It appears plausible that consumers' information processing is biased according to their environmental motives [31]. We argue that consumers are more inclined to evaluate both the green and the non-green attributes of a user entrepreneur more positive and that this application of motivated reasoning explains the differences in performance evaluations between consumers with weak vs. strong environmental values.

Some limitations of our study deserve attention. First, we build our research on a single online scenario experiment. We designed the study to strongly mirror previous research on the sustainability liability effect to ensure the comparability of our study setup with earlier work. Thus, our findings can be interpreted as an indicator of change in consumer perceptions. However, additional studies would strengthen the validity of our research. In particular, field studies examining the actual crowdfunding behavior of consumers could generate insights into the performance perceptions toward green vs. nongreen user innovators. Second, the scenarios in our experiment only described the profiles of male user entrepreneurs. We intentionally designed the profiles to avoid response biases based on gender effects. Previous research has documented a green-feminine stereotype and shown that consumers associate sustainable behavior with the female gender and perceive greenness as unmanly [32]. Hence, using male profiles is a stronger test for examining a sustainability liability effect. Specifically, consumers might perceive males to be less competent in innovating sustainable products, but in terms of a zero-sum evaluation, as more performant in business matters. Thus, differences in perceptions of business performance of green vs. non-green male innovators are harder to detect. In light of our results, we infer that consumers would value green female user innovators as particularly performant because they would be assessed as competent in innovating green products and because green innovations profit from the "sustainability asset" effect. Future research might test this assumption. Third, we investigated user entrepreneur performance 
perceptions of regular, non-professional consumers. We argue that knowledge of the beliefs of these rather naive, non-professionals is important because research on user entrepreneurs stresses the relevance of non-professionals in the process of starting their business. The creative and financial support of a social community that believes in the user entrepreneur is vital for the entrepreneurial progress. In comparison, professional investors who assess the future performance of user entrepreneurs use additional criteria to predict success.

\section{Conclusions}

This study proposes a novel perspective on the research on user entrepreneurship. Since user entrepreneurs strongly rely on regular consumers' support when starting their business, we investigate regular consumers' perceptions on user entrepreneurs.

Our findings have implications for theory and practice. First, this study contributes to research on the sustainability liability effect for perceived product performance. Overall, our results revealed that consumers did not devalue sustainable products. Instead, sustainable and less sustainable products were perceived as equally performant. When comparing product performance perceptions among consumers with high vs. low levels of environmental concern, we replicate recent findings $[21,30]$ and find a sustainability asset effect among environmentally concerned consumers. We interpret our results as a signal of a sustainability spirit in consumers' minds. Pressured by the rising urgency of environmental issues, consumers might become more acceptant of sustainable products. Faced also with an increasing choice of green products in various product domains, consumers have made firsthand experiences with the performance of green products. The first studies that demonstrated the sustainability liability effect were published in 2010 [13]. The most recent study on the topic that was published in 2020 [21] replicated the liability effect for consumers with weak environmental values only. Apparently, the liability effect seems to disappear in consumers' perceptions, and instead, sustainable product attributes are turning into a product asset.

Second, this study contributes to research on user entrepreneurs. We examine the "sustainability liability" phenomenon - a bias that has been studied in consumer researchin the domain of user entrepreneurship. We provide insights on consumer perceptions of user entrepreneur performance and extend prior research on the drivers of user entrepreneur motivation and success (e.g., $[4,19])$. In addition, we suggest to explore further research opportunities and encourage interdisciplinary research that combines innovation management and consumer research.

We also derive practical implications from our findings. Our results have potential consequences for consumers' investment decisions in supporting user entrepreneurs. Given that the standard assumption in the literature of decision making under risk implies that risk is negatively associated with the attractiveness of an option [33], consumers are likely to reduce perceived risk by focusing on attributes they perceive to be attractive. Our results imply that green user entrepreneurs will have an advantage compared to non-green alternatives when consumers make assessments about which user entrepreneur they want to support in terms of creative input, financial investment, etc.

Furthermore, this research is of relevance for user entrepreneur motivation when starting a business, in particular the effectiveness of social reputation as a motivational driver. Our findings indicate that consumers hold more positive beliefs in the performance of green user entrepreneurs. Thus, starting a business with sustainable offerings is likely to yield social appreciation and respect from others. While monetary incentives are clearly a driver of innovator engagement toward forming a (green) business [19], our findings imply that social incentives can further propel the rise of more sustainable entrepreneurial developments by users.

Overall, we take the optimistic view that prejudice against green products has started to disappear, even among consumers with weak environmental values, marking the onset of a sustainable consumption transition and opening a fruitful outlook for green businesses. 
Author Contributions: Conceptualization, J.M. and S.H.; methodology, J.M. and S.H.; software, J.M.; validation, J.M. and S.H.; formal analysis, J.M. and S.H.; investigation, J.M. and S.H.; resources, J.M. and S.H.; data curation, J.M. and S.H.; writing-original draft preparation, J.M. and S.H.; writing - review and editing, J.M. and S.H.; visualization, S.H.; supervision, J.M. and S.H.; project administration, J.M. and S.H. All authors have read and agreed to the published version of the manuscript.

Funding: This research received no external funding.

Institutional Review Board Statement: The study was conducted according to the guidelines of the Declaration of Helsinki, and according to the ethical guidelines of Freie Universität Berlin.

Informed Consent Statement: Informed consent was obtained from all subjects involved in the study.

Data Availability Statement: The data presented in this study are available on request from the corresponding author. The data are not publicly available.

Acknowledgments: The authors thank Jan Kratzer, Dodo zu Knyphausen-Aufseß and Gunter Festel for serving as editors for this Special Issue as well as Elissa Cotter, and Mark Wilson from the OPP group for their helpful comments. The publication of this article was funded by Freie Universität Berlin.

Conflicts of Interest: The authors declare no conflict of interest.

\section{Appendix A. User Innovator Profiles}

Meet James. He has an academic degree in natural sciences and now works in a large international company. In his spare time, he likes to come up with ideas to invent new products. He plans to start his own company soon and bring his latest innovation to market. Please read the description of James' innovation:

\section{Zapped Bug Spray}

Zapped Bug Spray uses an advanced powder-dry formula that dries on contact, leaving your skin feeling smooth and dry, not oily or greasy.

Sustainability information present: Zapped Bug Spray is made with sustainable plant-based ingredients and does not contain fabricated chemicals.

Meet John. He has an academic degree in natural sciences and now works in a large international company. In his spare time, he likes to come up with ideas to invent new products. He plans to start his own company soon and bring his latest innovation to market. Please read the description of Johns' innovation:

\section{Cleanse Laundry Detergent}

Cleanse laundry detergent delivers a premium clean for your everyday laundry that keeps whites white and colors vivid. Safe and effective for all fabrics and water temperatures.

Sustainability information present: Cleanse is made from a biodegradable HE formular containing plant-derived surfactants—no artificial chemicals.

Meet Robert. He has an academic degree in natural sciences and now works in a large international company. In his spare time, he likes to come up with ideas to invent new products. He plans to start his own company soon and bring his latest innovation to market. Please read the description of Robert's innovation:

\section{SunShield Sunscreen}

SunShield sunscreen is a non-chemical sunscreen lotion that delivers a refreshingly luxurious powdery clean feel, while the subtle tint seamlessly blends into any skin tone yet washes away with water. Rich in vitamins and antioxitands, it allows you to enjoy the sun your way, protected from both UVA and UVB rays. 
Sustainability information present: SunShield contains only natural ingredients—no chemicals or active elements.

Meet Michael. He has an academic degree in natural sciences and now works in a large international company. In his spare time, he likes to come up with ideas to invent new products. He plans to start his own company soon and bring his latest innovation to market. Please read the description of Michael's innovation:

\section{Coolpoint Air Conditioner}

Coolpoint air conditioner quickly cools down a room on hot days and removes harmful bacteria from the air with a removable antimicrobial mesh filter. It has multiple cool and fan settings and 2-way air direction to create the right level of comfort.

Sustainability information present: Coolpoint is an energy-efficient air conditioner that uses a new environmentally-friendly air refrigerant.

\section{Appendix B}

Table A1. Table of Key Measurement Constructs and Items.

\begin{tabular}{|c|c|c|c|c|}
\hline Construct & Source & Item(s) & Scale & $\begin{array}{c}\text { Reliability (Cronbach's } \\
\text { Alpha) }\end{array}$ \\
\hline $\begin{array}{l}\text { Perception of } \\
\text { product } \\
\text { performance }\end{array}$ & $\begin{array}{l}\text { Chernev and } \\
\text { Blair [21] }\end{array}$ & $\begin{array}{l}\text { How well do you believe Cleanse will } \\
\text { perform as a laundry detergent? }\end{array}$ & $\begin{array}{c}1=\text { Very poorly, } 9=\text { Very } \\
\text { well }\end{array}$ & n.a. \\
\hline $\begin{array}{l}\text { Perceptions of } \\
\text { user innovator } \\
\text { performance }\end{array}$ & $\begin{array}{l}\text { van Dyck } \\
\text { et al. [27] }\end{array}$ & $\begin{array}{l}\text { (a) To what extent will James' business } \\
\text { achieve its most important goals? (b) How } \\
\text { successful will James' business be in } \\
\text { comparison to other companies in the same } \\
\text { line of industry and of (about) the same size? }\end{array}$ & $\begin{array}{c}\text { (a) } 1=\text { Not at all, } \\
9=\text { Completely; }(\text { b) } \\
1=\text { Not at all successful, } \\
9=\text { Extremely successful }\end{array}$ & $\begin{array}{c}\alpha_{\text {overall }}=0.90 \\
\alpha_{\text {laundry }}=0.89 \\
\alpha_{\text {bug spray }}=0.92 \\
\alpha_{\text {sunscreen }}=0.89 \\
\alpha_{\text {air conditioner }}=0.88\end{array}$ \\
\hline $\begin{array}{l}\text { Perception of } \\
\text { product } \\
\text { sustainability }\end{array}$ & $\begin{array}{l}\text { Chernev and } \\
\text { Blair [21] }\end{array}$ & $\begin{array}{l}\text { (a) The new product is more environmentally } \\
\text { friendly than the average product in the } \\
\text { product category. (b) The new product is } \\
\text { better for society than the average product in } \\
\text { the product category. }\end{array}$ & $\begin{array}{c}1=\text { Strongly disagree, } \\
9=\text { Strongly agree }\end{array}$ & $\begin{array}{c}\alpha_{\text {overall }}=0.89 \\
\alpha_{\text {laundry }}=0.95 \\
\alpha_{\text {bug spray }}=0.89 \\
\alpha_{\text {sunscreen }}=0.85 \\
\alpha_{\text {air conditioner }}=0.87\end{array}$ \\
\hline $\begin{array}{l}\text { Environmental } \\
\text { values }\end{array}$ & $\begin{array}{l}\text { Chernev and } \\
\text { Blair [21] }\end{array}$ & $\begin{array}{l}\text { (a) It is important to me that the products I } \\
\text { use do not harm the environment. (b) I think } \\
\text { companies should be doing more to ensure } \\
\text { their products are sustainable. }\end{array}$ & $\begin{array}{c}1=\text { Strongly disagree } \\
9=\text { Strongly agree }\end{array}$ & $\alpha=0.77$ \\
\hline $\begin{array}{l}\text { Proactive } \\
\text { personality }\end{array}$ & $\begin{array}{l}\text { Bateman and } \\
\text { Crant [28]; see } \\
\text { also Kickuhl } \\
\text { and Gundry } \\
\text { [34] }\end{array}$ & $\begin{array}{l}\text { (a) I enjoy facing and overcoming obstacles to } \\
\text { my ideas. (b) Nothing is more exciting than } \\
\text { seeing my ideas turn into reality. (c) I excel at } \\
\text { identifying opportunities. (d) I love to } \\
\text { challenge the status quo. (e) I can spot a good } \\
\text { opportunity long before others can. }\end{array}$ & $\begin{array}{c}1 \text { = Strongly disagree, } \\
9 \text { = Strongly agree }\end{array}$ & $\alpha=0.84$ \\
\hline $\begin{array}{l}\text { Entrepreneurial } \\
\text { experience }\end{array}$ & $\begin{array}{c}\text { Own } \\
\text { development }\end{array}$ & Have you ever started your own business & yes $=1$, no $=0$ & n.a. \\
\hline
\end{tabular}

\section{References}

1. Maier, D.; Maier, A.; Așchilean, I.; Anastasiu, L.; Gavriș, O. The Relationship between Innovation and Sustainability: A Bibliometric Review of the Literature. Sustainability 2020, 12, 4083. [CrossRef]

2. von Hippel, E. Democratizing Innovation; The MIT Press: Cambridge, MA, USA, 2005.

3. Franke, N.; Schirg, F.; Reinsberger, K. The Frequency of End-User innovation: A Re-Estimation of Extant Findings. Res. Policy 2016, 45, 1684-1689. [CrossRef]

4. Shah, S.K.; Tripsas, M. When Do User Innovators Start Firms? A Theory of User Entrepreneurship. In Revolutionizing Innovation: Users, Communities and Open Innovation; Harhoff, D., Lakhani, K.R., Eds.; The MIT Press: Cambridge, MA, USA, 2016 ; pp. $285-307$.

5. Shah, S.K.; Tripsas, M. The Accidental Entrepreneur: The Emergent and Collective Process of User Entrepreneurship. Strateg. Entrep. J. 2007, 1, 123-140. [CrossRef] 
6. Agarwal, R.; Shah, S.K. Knowledge Sources of Entrepreneurship: Firm Formation by Academic, User and Employee Innovators. Res. Policy 2014, 43, 1109-1133. [CrossRef]

7. CGS 2020 Retail and Fashion Sustainability Survey. 2020. Available online: https://www.cgsinc.com/en/resources/surveyreveals-sustainability-shopping-preferences (accessed on 1 February 2021).

8. Banerjee, S.B.; Iyer, E.S.; Kashyap, R.K. Corporate Environmentalism: Antecedents and Influence of Industry Type. J. Mark 2003, 67, 106-122. [CrossRef]

9. Awan, U.; Khattak, A.; Rabbani, S.; Dhir, A. Buyer-Driven Knowledge Transfer Activities to Enhance Organizational Sustainability of Suppliers. Sustainability 2020, 12, 2993. [CrossRef]

10. Johnstone, M.L.; Tan, L.P. Exploring the Gap Between Consumers' Green Rhetoric and Purchasing Behaviour. J. Bus. Ethics 2015, 132, 311-328. [CrossRef]

11. White, K.; Habib, R.; Hardisty, D.J. How to SHIFT Consumer Behaviors to be More Sustainable: A Literature Review and Guiding Framework. J. Mark. 2019, 83, 22-49. [CrossRef]

12. Verplanken, B.; Roy, D. Empowering Interventions to Promote Sustainable Lifestyles: Testing the Habit Discontinuity Hypothesis in a Field Experiment. J. Environ. Psychol. 2016, 45, 127-134. [CrossRef]

13. Luchs, M.G.; Naylor, R.W.; Irwin, J.R.; Raghunathan, R. The Sustainability Liability: Potential Negative Effects of Ethicality on Product Preference. J. Mark. 2010, 74, 18-31. [CrossRef]

14. Newman, G.E.; Gorlin, M.; Dhar, R. When Going Green Backfires: How Firm Intentions Shape the Evaluation of Socially Beneficial Product Enhancements. J. Consum. Res. 2014, 41, 823-839. [CrossRef]

15. Gambardella, A.; Raasch, C.; von Hippel, E. The User Innovation Paradigm: Impacts on Markets and Welfare. Manag. Sci. 2017, 63, 1450-1468. [CrossRef]

16. von Hippel, E. Lead Users: A Source of Novel Product Concepts. Manag. Sci. 1986, 32, 791-805. [CrossRef]

17. Moreau, C.P.; Franke, N.; von Hippel, E. The Paradigm Shift from Producer to Consumer Innovation: Implications for Consumer Research. In Handbook of Research on New Product Development; Golder, P.N., Mitra, D., Eds.; Edward Elgar Publishing: Cheltenham, UK, 2018; pp. 81-99. [CrossRef]

18. Shah, S.K.; Winston Smith, S.; Reedy, E.J. Who are User Entrepreneurs? In Findings on Innovation, Founder Characteristics, and Firm Characteristics (The Kauffman Firm Survey) (February 2012); Ewing Marion Kauffman Foundation: Kansas City, MO, USA, 2012. [CrossRef]

19. Hamdi-Kidar, L.; Vellera, C. Triggers Entrepreneurship among Creative Consumers. J. Bus. Res. 2018, 92, 465-473. [CrossRef]

20. Oo, P.P.; Allison, T.H.; Sahaym, A.; Juasrikul, S. User Entrepreneurs' Multiple Identities and Crowdfunding Performance: Effects through Product Innovativeness, Perceived Passion, and Need Similarity. J. Bus. Ventur. 2019, 34, 105895. [CrossRef]

21. Chernev, A.; Blair, S. When Sustainability is Not a Liability: The Halo Effect of Marketplace Morality. J. Consum. Psychol. 2020, Early View. 1-19. [CrossRef]

22. Lin, Y.-C.; Chang, C.-C.A. Double Standard: The Role of Environmental Consciousness in Green Product Usage. J. Mark. 2012, 76, 125-134. [CrossRef]

23. Essoussi, L.H.; Linton, J.D. New or recycled products: How much Are Consumers Willing to Pay? J. Consum. Mark. 2010, 27, 458-468. [CrossRef]

24. Chernev, A. Jack of All Trades or Master of One? Product Differentiation and Compensatory Reasoning in Consumer Choice. J. Consum. Res. 2007, 33, 430-444. [CrossRef]

25. Chernev, A.; Carpenter, G.S. The Role of Market Efficiency Intuitions in Consumer Choice: A Case of Compensatory Inferences. J. Mark. Res. 2001, 38, 349-361. [CrossRef]

26. Reed, A.; Aquino, K.; Levy, E. Moral Identity and Judgments of Charitable Behaviors. J. Mark. 2007, 71, 178-193. [CrossRef]

27. Van Dyck, C.; Frese, M.; Baer, M.; Sonnentag, S. Organizational Error Management Culture and Its Impact on Performance: A Two-Study Replication. J. Appl. Psychol. 2005, 90, 1228-1240. [CrossRef]

28. Bateman, T.S.; Crant, J.M. The Proactive Component of Organizational Behavior: A Measure and Correlates. J. Organ. Behav. 1993, 14, 103-118. [CrossRef]

29. Krishna, A. A Clearer Spotlight on Spotlight: Understanding, Conducting and Reporting. J. Consum. Psychol. 2016, 26, 315-324. [CrossRef]

30. Haws, K.L.; Winterich, K.P.; Naylor, R.W. Seeing the World through GREEN-Tinted Glasses: Green Consumption Values and Responses to Environmentally Friendly Products. J. Consum. Psychol. 2014, 24, 336-354. [CrossRef]

31. Kunda, Z. The Case for Motivated Reasoning. Psychol. Bull. 1990, 108, 480-498. [CrossRef] [PubMed]

32. Brough, A.R.; Wilkie, J.E.; Ma, J.; Isaac, M.S.; Gal, D. Is Eco-Friendly Unmanly? The Green-Feminine Stereotype and Its Effect on Sustainable Consumption. J. Consum. Res. 2016, 43, 567-582. [CrossRef]

33. March, J.G.; Shapira, Z. Managerial Perspectives on Risk and Risk Taking. Manage. Sci. 1987, 33, 1404-1418. [CrossRef]

34. Kickul, J.; Gundry, L. Prospecting for Strategic Advantage: The Proactive Entrepreneurial Personality and Small Firm Innovation. J. Small Bus. Manag. 2002, 40, 85-97. [CrossRef] 